\title{
Establishment of Chydorus sphaericus (O.F. Müller, 1785) (Crustacea: Cladocera) in Australia: consequences of mass fish stocking from Northern Europe?
}

\author{
Pranay SHARMA, ${ }^{1 *}$ Alexey A. KOTOV 2,3 \\ ${ }^{1}$ School of Earth and Environmental Science, University of Adelaide, SA 5005, Australia; ${ }^{2}$ A.N. Severtsov Institute of Ecology and Evolution, \\ Leninsky Prospect 33, Moscow 119071, Russia; ${ }^{3}$ Kazan Federal University, Kremlevskaya Str.18, Kazan 420000, Russia \\ *Corresponding author: pranay.sharma@adelaide.edu.au; pranaysharma19@gmail.com
}

\begin{abstract}
There are 11 species of genus Chydorus Leach, 1816 (Cladocera: Chydoridae) in Australia, including populations of Chydorus sphaericus (O.F. Müller, 1785) morphologically undistinguishable from European ones. Our genetic study of C. sphaericus from two large artificial water bodies in the Adelaide region of South Australia led us to conclude the taxon was introduced to Australia from Europe by human activity, at least in the two studied water bodies. To provide a comprehensive sister-taxa coverage and survey of intraspecific variation, our data were complemented by sequences on Chydorus sphaericus-group from GenBank and Barcode of Life Data Systems website. We speculate that it was related to a mass stocking of introduced species of fishes from Europe. To confirm whether C. sphaericus is an invasive species due to human-mediated introductions, or whether it is a native Australian taxon, further extensive molecular studies (involving nuclear genes) and detailed morphological comparisons are needed. This is a first report on the invasion of a non-daphniid species of Cladocera to Australia. Its significance for Australian ecosystems needs special future studies.
\end{abstract}

Key words: C. sphaericus, Australia, Northern Europe, South Australia.

Received: June 2014. Accepted: September 2014.

\section{INTRODUCTION}

One of the main goals of modern biology is to identify and differentiate species in different groups of organisms. Cladocera (Crustacea: Branchiopoda) is a well-known superorder of freshwater animals present in all continents, including Antarctica, with well-known differences in identification and discrimination of species (Forró et al., 2008). Chydoridae Dybowski \& Grochowski, 1894 emend. Frey, 1967, is the largest family of order Anomopoda Sars, 1865 and Cladocera in toto. The former contains more than half of all described species of Cladocera. Chydorids have attracted the attention of hydrobiologists since the pioneering publications on Cladocera (Müller, 1776, 1785).

Chydorids were the primary organisms of Frey's (1985, 1987) studies which led to the well-known and widely accepted conclusion that cladoceran species display a noncosmopolitanism in their distribution. Subsequently, continental endemism and regionalism were found to be common patterns for other cladoceran families (Smirnov, 1976; Haney and Taylor, 2003; Adamowicz et al., 2004; Korovchinsky, 2004; Bekker et al., 2012) and orders (Korovchinsky, 2004; Xu et al., 2009; Millette et al., 2011).

In the past two decades, hydrobiologists have examined chydorids more critically, taking into consideration morphological characters such as head pores, mandibular articulation, trunk limb setation and by comparing populations from different continents with those from type localities (Frey, 1993; Kotov, 2009; Van Damme et al., 2011; Sinev and Kotov, 2012; Van Damme and Sinev, 2013). These observations have resulted in a significant increase in the number of known species from different continents. The first publications on phylogenetics (Sacherová and Hebert, 2003) and barcoding (Elias-Gutierrez et al., 2008; Jeffery et al., 2011) of chydorids have appeared recently, although most recent geneticists work with a single genus Daphnia Müller, 1785.

Among chydorids, there are many well-recognised, small and relatively well-studied genera, and several large genera with a confused taxonomy, such as Alona Baird, 1843 (subfamily Aloninae), Pleuroxus Baird, 1843 or Alonella Sars, 1862 (subfamily Chydorinae) (Smirnov 1971, 1996). Probably the most common chydorid genus, which is present in a majority of tropical, temperate and even polar water bodies, is Chydorus Leach, 1816 (subfamily Chydorinae). Species of this genus are more frequently recorded in hydrobiological publications as compared with other chydorids, because the former usually occur in plankton - the primary object of hydrobiological studies. Smirnov (1996) listed 30 valid species in the world fauna, but this number was significantly underestimated, and some new species were subsequently added, i.e., by Smirnov and Sheveleva (2010). The genus contains several taxa now regarded as cosmopolitan or tropicopolitan, which seem to be complexes of congener species with a relatively wide or very narrow distribution 
(Frey, 1987; Smirnov, 1996; Belyaeva and Taylor, 2009).

Four species of Chydorus have been recorded from Australia by Smirnov and Timms (1983). Two other taxa, C. barroisi (Richard, 1894) and C. hybridus Daday (1905), were transferred to Ephemeroporus Frey (1982). When Smirnov \& Timms submitted their publication, they did not know about Frey's paper (1982). Most recently, Shiel and Dickson (1995) and Smirnov (1995) list 11 valid Australian species: C. eurynotus Sars, 1901; C. clelandi Henry, 1919; C. herrmanni Brehm, 1933; C. kallipigos Brehm, 1933; C. obscurirostris Frey, 1987; C. opacus Frey, 1987; C. ovalis Kurz, 1874; C. parvus Daday, 1898; C. pubescens Sars, 1901; C. reticulatus Daday, 1898; C. sphaericus (Müller, 1785). Some of these taxa definitively form groups of congener species and need to be revised worldwide (Smirnov, 1996).

Chydorus sphaericus-like populations are common in Australia (Smirnov and Timms, 1983). Smirnov (1971) and Frey $(1980,1985,1987)$ studied Chydorus sphaericus s.lat. in detail. This taxon was regarded as cosmopolitan for a long time, although similar forms were described from different continents, sometimes based on very dubious diagnostic characters. For example, a special name has been suggested for Australian sphaericus-like populations, $C$. leonardi King, 1853, but any differences between this and C. sphaericus s.str. are unknown. Frey (1980), Shiel and Dickson (1995) and Smirnov (1995) concluded that $C$. sphaericus in Australia is a species complex, none of which is actually C. sphaericus s.str. - the latter is present in Eurasia only. Smirnov (1996) found some populations in Australia that were undistinguishable from European populations and concluded that the distribution of this taxon is Holarctic and probably worldwide. Belyaeva and Taylor (2009) genetically analysed the Holarctic populations and recognised at least six well-differentiated clades in the $C$. sphaericus group, some of them locally distributed. Later Jeffery et al. (2011) found even more taxa from this complex in Arctic Canada.

The objective of the present study was to consider all available data, morphological and molecular (ribosomal and nuclear genes), of the C. sphaericus to clarify the taxonomical position of Australian C. sphaericus.

\section{METHODS}

\section{Studied water bodies}

South Para reservoir (completed in 1958) is situated approximately $60 \mathrm{~km}$ north of Adelaide (Fig. 1). It has a surface area of $4 \mathrm{~km}^{2}$, and a storage capacity of approximately 45,330 ML with a maximum depth of $42 \mathrm{~m}$ at full supply level. South Para reservoir receives water from its catchment, which covers an area of $326 \mathrm{~km}^{2}$ and occasionally supplemented from River Murray through the Mannum pipeline.
Myponga reservoir (completed in 1962) is situated approximately $70 \mathrm{~km}$ south of Adelaide. It has a surface area of $2.8 \mathrm{~km}^{2}$, and a storage capacity of approximately $26,800 \mathrm{ML}$ with a maximum depth of $42 \mathrm{~m}$ at full supply level (Brookes et al., 2005). It receives water solely from its catchment, which covers an area of $124 \mathrm{~km}^{2}$. It is intensively managed using artificial aeration and destratification from two surface mechanical mixers and multi-diffuser bubble-plume aerators to control cyanobacterial growth (Lewis et al., 2001).

\section{Zooplankton sampling}

In February 2010, abundant ovigerous females of $C$. sphaericus were collected in two reservoirs, using a conical plankton net with a mesh size of $35 \mu \mathrm{m}$. The plankton net was towed behind a boat for 5-7 min at a speed of about $2 \mathrm{~m} \mathrm{~s}^{-1}$ in mid open water (Suthers and Rissik, 2009). Specimens were fixed and preserved in the field with denatured ethanol to obtain a final concentration of alcohol of $70 \%$, and then stored in $200 \mathrm{~mL}$ Cospak PET bottles.

\section{Morphological identification}

Specimens were selected from preserved samples under a binocular stereoscopic microscope, and studied under an optical microscope in a drop of glycerol. Ten parthenogenetic females from each locality were dissected under a stereoscopic microscope for the study of appendages and postabdomen, under a high-power Olympus BX51 microscope, to check the identity of Australian populations of C. sphaericus, with those from Europe (Frey, 1980, 1985; Alonso, 1996; Belyaeva and Taylor, 2009). Digital photographs were taken using Olympus BX51 microscope under high resolution using the polarizing photography, and composite line drawings were made from these photographs for different parts of the specimens. The inbuilt imaging software Image $J^{\circledR}$ was used for measurements.

\section{Molecular methods}

Ten specimens of ovigerous females of $C$. sphaericus were selected from material collected from each reservoir, to examine their genetic variability. Total genomic DNA was extracted for each specimen using QIAMP ${ }^{\circledR}$ DNA extraction kits as described in the manufacturer's protocol. Polymerase chain reaction (PCR) was used to amplify an approximately $680 \mathrm{bp}$ fragment of the COI gene with Folmer primer pair (LCO 1490 and HCO 2198) (Folmer et al., 1994). Each $50 \mu \mathrm{L}$ PCR reaction consisted of $5 \mu \mathrm{L}$ of genomic DNA template, $3 \mu \mathrm{L}$ of 50 $\mathrm{mM} \mathrm{MgCl} 2,5 \mu \mathrm{L}$ of $10 \mathrm{X}$ Buffer, $1.5 \mu \mathrm{L}$ of each primer, $1 \mu \mathrm{L}$ of $10 \mu \mathrm{M}$ dNTP's, $0.24 \mu \mathrm{L}$ of Taq platinum polymerase and $32.76 \mu \mathrm{L}$ of DNA free Milli-Q water. PCR 
profile consisted of an initial hot start $(2 \mathrm{~min} 30 \mathrm{sec}$ at $94^{\circ} \mathrm{C}$ ) for $1 \mathrm{~min}$ followed by: 5 cycles each of $94^{\circ} \mathrm{C}$ for $35 \mathrm{~s}, 48^{\circ} \mathrm{C}$ for $40 \mathrm{~s}$ and $72^{\circ} \mathrm{C}$ for $1 \mathrm{~min}$; followed by 35 cycles each of $94^{\circ} \mathrm{C}$ for $30 \mathrm{~s}, 56^{\circ} \mathrm{C}$ for $40 \mathrm{~s}$ and $72^{\circ} \mathrm{C}$ for $1 \mathrm{~min}$, finishing with a step of $72^{\circ} \mathrm{C}$ for $10 \mathrm{~min}$. PCR products were run in $2 \%$ agarose gels containing $10 \mu \mathrm{L}$ of SYBR ${ }^{\circledR}$ Safe DNA gel stain (Invitrogen Inc., Carlsbad, CA, USA) for 2 to $4 \mathrm{~h}$ at 80 to $100 \mathrm{~V}$ and visualized using UV-transillumination. The amplified bands were sharp and clean, which were cut and purified from the agarose gel using QIAquick ${ }^{\circledR}$ Gel Extraction Kit.

The sequencing reaction for both forward and reverse directions involved: $0.5 \mu \mathrm{L}$ of primer, $1 \mu \mathrm{L}$ of Big Dye Terminator v 3.1, 3.5 $\mu \mathrm{L}$ of sequencing buffer and 1 to $3 \mu \mathrm{L}$ of purified PCR product. Concentration of PCR product was as follows: $1 \mu \mathrm{L}$ of the purified PCR product for strong band with DNA concentration $>8 \mathrm{ng}$ $\mu \mathrm{L}^{-1}, 2 \mu \mathrm{L}$ for moderate band with DNA concentration between 3 to $5 \mathrm{ng} \mu \mathrm{L}^{-1}$ and $3 \mu \mathrm{L}$ for weak band with DNA concentration $<3 \mathrm{ng} \mu \mathrm{L}^{-1}$, with the total volume made up to $25 \mu \mathrm{L}$ using DNA free Milli-Q water. Sequencing thermal cycle consisted of 1 cycle of $1 \mathrm{~min}$ at $95^{\circ} \mathrm{C}$, followed by 25 cycles of $95^{\circ} \mathrm{C}$ for $15 \mathrm{~s}, 50^{\circ} \mathrm{C}$ for $10 \mathrm{~s}$ and $60^{\circ} \mathrm{C}$ for $4 \mathrm{~min}$ with final overnight incubation at $25^{\circ} \mathrm{C}$. Sequencing product was then purified using MilliporeTM384 - SEQ Filter plates using 1X Tris Buffer. The purified PCR products along with primers (LCO1490 and HCO2198) were sent to the Australian Genome Research Facility Ltd., Australia and Macrogen Inc., South Korea, for sequencing on the AB 3730xl Platform sequencer. Both forward and reverse genomic strands were sequenced to confirm the accuracy of each haplotype sequence. DNA sequences were edited using Bioedit (ver. 7.0.0) and aligned using Clustal W (Thompson et al., 1994), using Gap open penalty set to 100 , so that gaps became less frequent. Estimates of se-
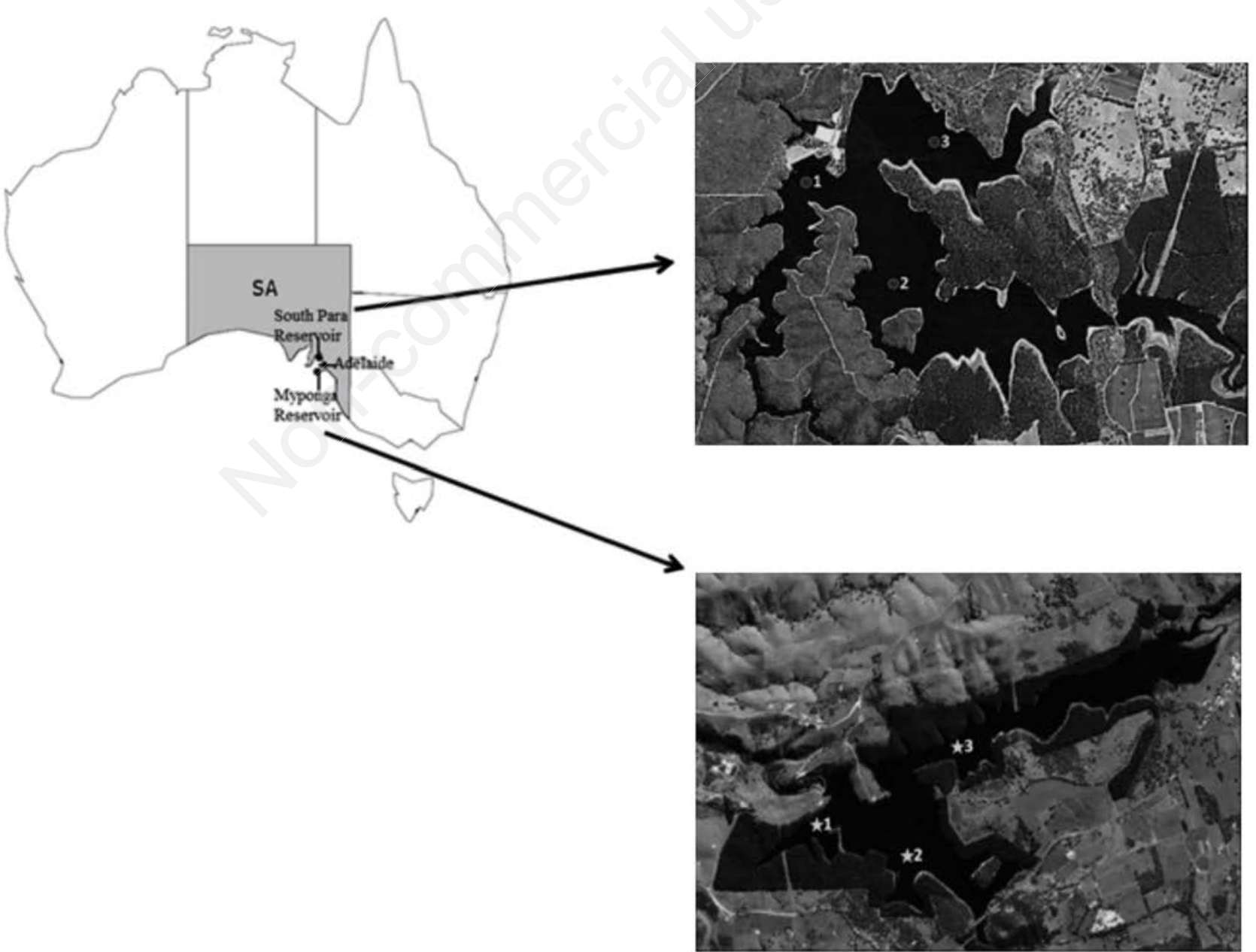

Fig. 1. South Para and Myponga reservoirs with sampling sites. Legends: filled circles and stars represents permanent pelagic sampling sites. Image taken from Google maps on the $4^{\text {th }}$ April 2011. 
quence divergence were calculated for COI gene using the Kimura 2-parameter (K2P) distance model (Kimura, 1980) and a simplified tree was constructed using the Mega 5 software (Tamura et al., 2011). Branch support values were estimated using 1000 bootstrap replicates. All other parameters were set to their default values.

\section{GenBank dataset}

To provide a comprehensive sister-taxon coverage and survey of intraspecific variation, our data were complemented by sequences on Chydorus sphaericus-group from GenBank and Barcode of Life Data Systems websites, with the total number of sequences $=139$, number of haplotypes $=79$, as available on 20 October 2012 .

GenBank sequence ID names were formatted with accession numbers provided from GenBank for downloaded sequences. Haplotypes were identified using Collapse 1.2 (Posada and Buckley, 2004). Barcode sequences generated from this study and those extracted from GenBank were aligned using Clustal W application implemented in software Bioedit Ver.7.0.0. (Hall, 1999) using Gap open penalty set to 100 , so that gaps become less frequent.

\section{Phylogenetic analysis}

The best fit models of nucleotide substitution were selected using the Model Generator (Keane et al., 2006) and the Maximum Likelihood (ML) tree was constructed using PhyML ver. 3.0 (Guindon and Gascuel, 2003). Following parameter settings were used for phylogenetic analysis: input sequences in interleaved format; best model of the nucleotide substitution was selected from Model Generator; transition/transversion ratio and proportion of invariable nucleotide sites estimated by PhyML; a BIONJ tree was initially used; tree topology search option was set to Best of Nearest Neighbour Interchange (NNI) and Subtree Pruning and Regrafting (SPR) with random starting tree set at 5; non-parametric bootstrap analysis was set to YES with 1000 replicates. Within and among clade, distances were calculated and $\mathrm{NJ}$ phylogenetic analyses were carried out in MEGA 5.0 using model and gamma rates distribution with the shape parameter estimated by JModelTest and with pairwise deletion of gaps.

Bayesian analyses were performed by using Mr. Bayes v. 3.0 (Huelsenbeck et al., 2001). Number of substitution types was set to 6 and the rates were set to gamma with a proportion of invariable sites. All priors were left to default to allow estimation of parameters from data. Four independent Markov Chain Monte Carlo analyses were run simultaneously for 2 million generations and sampled every 500 generations. The first $25 \%$ generations were discarded as the burn-in and a 50\% majority rule consensus tree was calculated from remaining trees.

\section{RESULTS}

\section{Morphological diagnosis of the $C$. sphaericus species complex}

Chydorus specimens from two South Australian reservoirs (Fig. 2) clearly belongs to C. sphaericus group, which is characterized by the following parthenogenetic female characters: i) sub-globular body; ii) pointed rostrum; iii) triangular labral keel with a sharply pointed tip; iv) a small flap on inner face of valve near its anterior margin; v) no denticles in postero-ventral portion of valve; vi) postabdomen relatively narrow, with well-expressed preanal angle; vii) teeth on postanal margin of postabdomen small; viii) antenna I with aesthetascs only in terminal position, and with a sensory seta in its middle; ix) antenna II with setae: $0-0-3 / 0-1-3 ; x$ ) inner distal lobe of limb I with a small seta and two large setae of which one is additionally chitinised. Unfortunately, morphological characters of parthenogenetic females alone are insufficient to determine exact species within the sphaericus-group (Belyaeva and Taylor, 2009).

\section{Mitochondrial gene tree}

A 510 bp fragment of the COI gene was successfully amplified for Chydorus sp. (number of haplotypes=2). The intraspecific divergence was $0 \%$ (raw and ML-corrected divergences), whereas interspecific variation was 3\% (raw and ML-corrected divergences) when compared with $C$. sphaericus from Germany (EU719127.1 and EU719129.1) (Fig. 3). The Australian haplotypes belong to Chydorus sphaericus $\mathrm{s}$.str. and are definitively grouped with a small sub-clade Clade A of Belyaeva and Taylor (2009), containing haplotypes from Iceland and Greenland.

\section{DISCUSSION AND CONCLUSIONS}

Chydorus sphaericus from South Australia shows a close genetic similarity with C. sphaericus from Europe, and the former is especially close to populations from Iceland and Greenland. Genetic similarity between South Australian and Holarctic haplotypes indicates the former are not continental endemics and their transfer from the original distributional range to Australia was very recent. Such cases are mainly explained by human activity.

The expansion of geographical distribution of species via anthropogenic factors is common and has been reported previously for many planktonic crustaceans such as copepods (Gutierrez-Aguirre and Suárez-Morales, 2000; Suárez-Morales et al., 2005; Duggan et al., 2006; Briski et al., 2011b; Sukhikh et al., 2013). Cladocerans are among the most famous invaders of water bodies due to their destructive effect on native ecosystems. For example, invasive predatory onychopods have significantly reduced zooplankton species richness in the Great Lakes of North America (Yan et al., 2002), Baltic Sea 

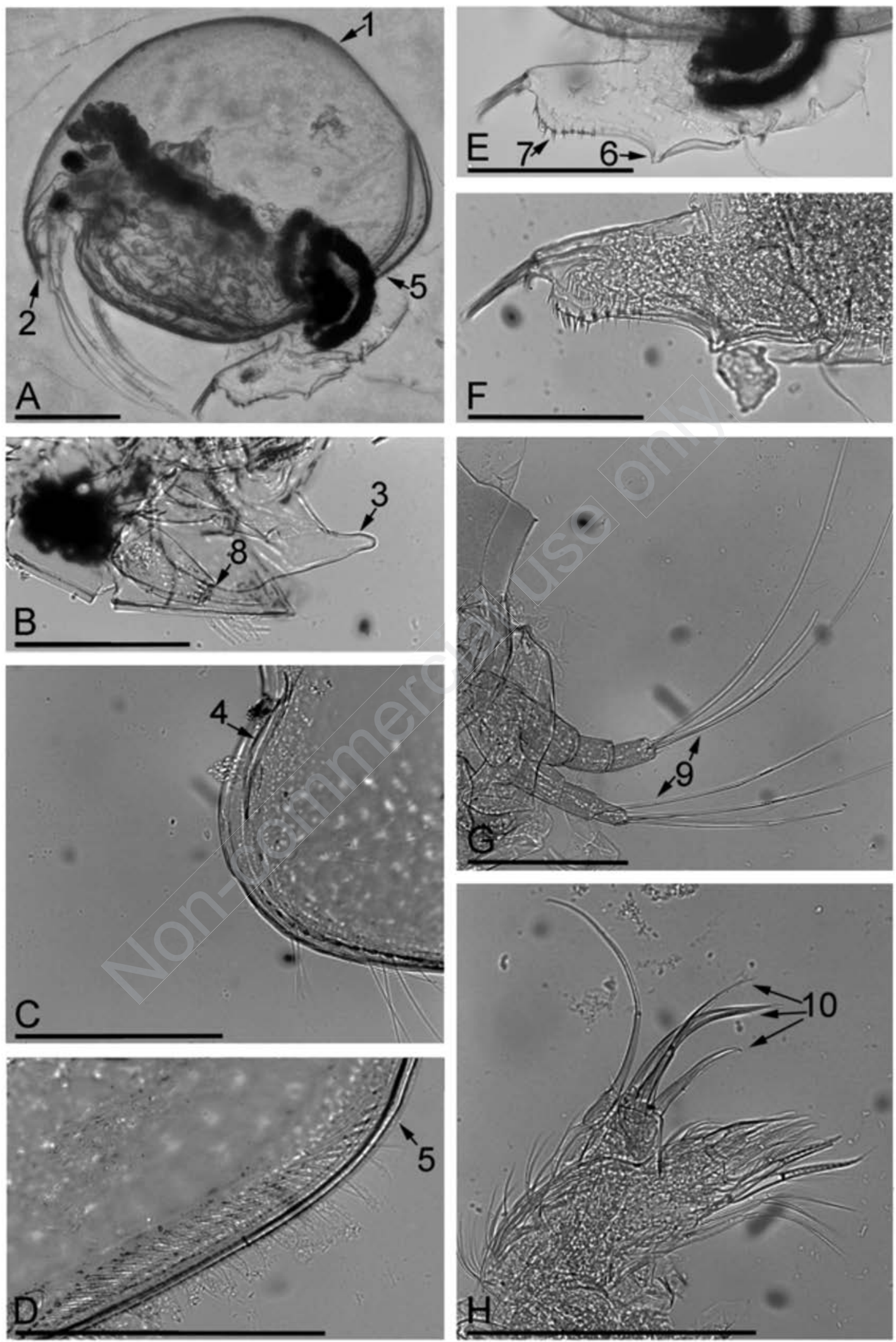

Fig. 2. Parthenogenetic female of Chydorus sphaericus from Myponga reservoir: A) General view; B) Head; C) Anterior portion of valve, inner view; D) Postero-ventral portion of valve, inner view; E-F) Postabdomen, lateral view; G) Antenna II; H) Limb I. Scale bars: $0.1 \mathrm{~mm}$. Numbers correspond to diagnostic characters of $C$. sphaericus group listed in the text. 
(Gorokhova et al., 2000), and in a large artificial reservoir on the Volga River, Russia (Panov et al., 2007).

The most famous cladoceran invaders are species of Daphnia. Different directions of invasions are revealed. European Daphnia pulex has been transferred in ballast tanks of transoceanic ships to North American Great Lakes (Briski et al., 2011). In contrast, a massive stock of $\mathrm{Mi}$ cropterus salmoides (largemouth bass) from USA to East Africa was accompanied by the appearance of an American asexual pulex-like lineage, which now has successively replaced native species of Daphnia in many African water bodies (Mergeay et al., 2005), except for on high mountains, where some native endemic species survived (Kotov and Taylor, 2010).

Perhaps the most successive invader is D. lumholtzi Sars, 1885, which was introduced together with African blue tilapia or/and nile perch to southern USA (Sorensen and Sterner, 1992), and which has now colonized all of the USA (Benson et al., 2013), Mexico (Elias-Gutierrez et al., 2008), Brazil (Zanata et al., 2003) and Argentina (Kotov and Taylor, 2014).

Several exotic species of Daphnia have already appeared in Australia: the Palaearctic D. obtusa Kurz, 1874 (Benzie and Hodges, 1996), D. dentifera Forbes, 1893 (Duggan et al., 2006) from North America and East Asia and aforementioned North American asexual D. pulex lineage (Duggan et $a l ., 2012)$. The latter authors speculated that the appearance of $D$. pulex in New Zealand was related to mass stocking to this country of several species of fishes (brown trout, rainbow trout and land-locked salmon) from North America.

In the $19^{\text {th }}-20^{\text {th }}$ century Australia was a target for mass stocking of several introduced species of fishes from Europe, mainly brown trout, Atlantic salmon, European carp, European perch from the United Kingdom (Fletcher, 1986; Morgan et al., 2004). Each of these fish species has been introduced several times to different parts of the continent, and then Australian populations have often been used for artificial dispersion across Australia. Among non-native fishes, European carp (Cyprinus carpio) has the strongest impact on native ecosystems (Koehn et al., 2000). Several genetic strains of European carp from different regions of Europe (England and Prussia) and later European carp from tropical Asia were introduced (Koehn et al., 2000). We do not have enough data to associate the appearance of Chydorus sphaericus in Australia with a certain campaign to stock European fish, but it is highly likely that in the course of such introductions, the ephippia from northern Europe were occasionally brought to Australia.

\section{CONCLUSIONS}

At present, we cannot say that our assumption for the two populations from South Australia of European $C$. sphaericus s.str. can be applied to the whole of Australia. It is possible that other populations of Chydorus in Aus- tralian water bodies might belong to other taxa, or could even be endemic to Australia. But there is also a chance that in the course of numerous transportations and simultaneous introduction of fishes within Australia, this continent was widely infected by $C$. sphaericus. To confirm whether $C$. sphaericus is an invasive species due to human-mediated introductions, or whether it is a native Australian taxon, further extensive molecular studies (involving nuclear genes) and detailed morphological comparisons are needed. This is a first report on the invasion of a non-daphniid species of Cladocera in Australia.

The use of molecular methods in studies of invasive species has added a new dimension to the traditional morphological approach. The former allows us to understand some valuable traits of the invasive process, such as an exact geographic region of origin of an invasive species. Use of genetic tools, such as DNA barcoding, could be important for the identification of organisms, in addition to traditional morphological descriptors (Costa et al., 2007; Ferri et al., 2009). The success in using sequences from COI gene region to distinguish phylogroups (species, intra-specific groups and haplotypes) and to reveal hidden species diversity in the Cladocera (ElíasGutiérrez et al., 2008; Belyaeva and Taylor, 2009) has been remarkable. But this method, however, is only effective for those species which have been studied extensively in the past, with well-documented morphology, reproduction, ecology and geographical distribution (Sites and Marshall, 2004). Nevertheless, combining morphology and molecular data has been found to be more successful for species recognition, identification and refinement (Ferri et al., 2009).

Some invaders are very destructive for ecosystems like D. lumholtzi in the Americas (Sorensen and Sterner, 1992) or carp in Australia (Koehn et al., 2000). At this moment we do not have any ideas on significance of the introduction of Chydorus sphaericus for Australian ecosystems, this question requires special studies.

\section{ACKNOWLEDGMENTS}

PS is grateful to the Sir Mark Mitchell Research Foundation, ANZ Holsworth Grant and ABRS Travel Bursary for financial support. The authors greatly appreciate Dr. Tsuyoshi Kobayashi and Dr. John Jennings for their helpful comments and suggestions on the manuscript. Thanks are also offered to Ms. Samantha-Ann Schneider for improving the English text. The authors extend their sincere thanks to SA Water, Microbiology Department, for granting permission and providing us with the necessary facilities to carry out the genetic work. We would like to thank the two anonymous referees for providing us with constructive comments and suggestions. AAK was supported by Russian Government Program of Competitive Growth of Kazan Federal University. 


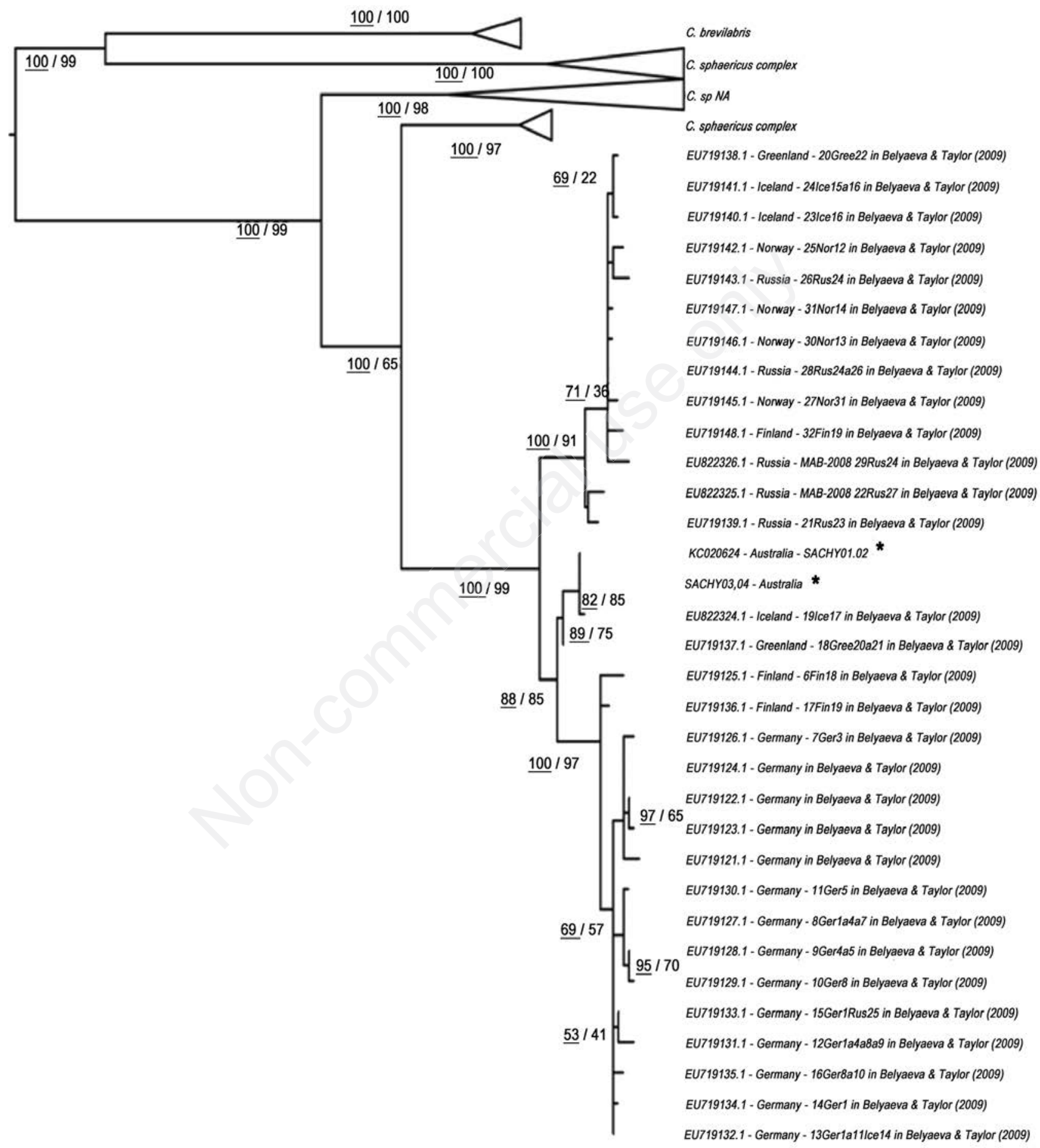

\section{$3 \%$ divergence}

Fig. 3. Maximum likelihood analysis of COI gene for the Chydorus sphaericus complex. Numbers above branches are Maximum likelihood (100 replicates) and underlined numbers are from Bayesian analysis. Asterisk represents sequences from the current study. 


\section{REFERENCES}

Adamowicz SJ, Hebert PD, Marinone MC, 2004. Species diversity and endemism in the Daphnia of Argentina: a genetic investigation. Zool. J. Linn. Soc.-Lond. 140:171-205.

Alonso M, 1996. [Crustacea Branchiopoda].[Book in Spanish]. Consejo Superior de Investigaciones Científicas, CSIC, Museo Nacional de Ciencias Naturales: 486 pp.

Bekker EI, Kotov AA, Taylor DJ, 2012. A revision of the subgenus Eurycercus (Eurycercus) Baird, 1843 emend. nov. (Cladocera: Eurycercidae) in the Holarctic with the description of a new species from Alaska. Zootaxa 3206:1-40.

Belyaeva M, Taylor DJ, 2009. Cryptic species within the Chydorus sphaericus species complex (Crustacea: Cladocera) revealed by molecular markers and sexual stage morphology. Mol. Phylogenet. Evol. 50:534-546.

Benson A, Maynard E, Raikow D, Larson J, Fusaro A, 2013. Daphnia lumholtzi. USGS Nonindigenous Aquatic Species Database, Gainesville, FL. Available from: http://nas.er.usgs. gov/queries/FactSheet.aspx?speciesID=164

Benzie JAH, Hodges AMA, 1996. Daphnia obtusa Kurz, 1874 emend Scourfield, 1942 from Australia. Hydrobiologia 333: 195-199.

Briski E, Cristescu ME, Bailey SA, Macisaac HJ, 2011. Use of DNA barcoding to detect invertebrate invasive species from diapausing eggs. Biol. Invasions 13:1325-1340.

Costa FO, Dewaard JR, Boutillier J, Ratnasingham S, Dooh RT, Hajibabaei M, Hebert PDN, 2007. Biological identifications through DNA barcodes: the case of the Crustacea. Can. J. Fish. Aquat. Sci. 64:272-295.

Daday VE, 1905. [Untersuchungen über die Süsswasser-Mikrofauna Paraguays].[Book in German]. E. Nägele: 374 pp.

Duggan IC, Green JD, Burger DF, 2006. First New Zealand records of three non-indigenous zooplankton species: Skistodiaptomus pallidus, Sinodiaptomus valkanovi, and Daphnia dentifera. New Zeal. J. Mar. Fresh. 40:561-569.

Duggan IC, Robinson KV, Burns CW, Banks JC, Hogg ID, 2012. Identifying invertebrate invasions using morphological and molecular analyses: North American Daphnia 'pulex' in New Zealand fresh waters. Aquatic Invasions 7:585-590.

Elias-Gutiérrez M, Jerónimo FM, Ivanova NV, Valdez-Moreno M, Hebert PD, 2008. DNA barcodes for Cladocera and Copepoda from Mexico and Guatemala, highlights and new discoveries. Zootaxa 1839:1-42.

Ferri E, Barbuto M, Bain O, Galimberti A, Uni S, Guerrero R, Ferte H, Bandi C, Martin C, Casiraghi M, 2009. Integrated taxonomy: traditional approach and DNA barcoding for the identification of filarioid worms and related parasites (Nematoda). Front. Zool. 6:1.

Fletcher AR, 1986. Effects of Introduced Fish in Australia. Limnology in Australia. Monogr. Biol. 61:231-238.

Forró L, Korovchinsky NM, Kotov AA, Petrusek A, 2008. Global diversity of cladocerans (Cladocera; Crustacea) in freshwater. Hydrobiologia 595:177-184.

Frey DG, 1980. On the plurality of Chydorus sphaericus (O.F. Müller) (Cladocera, Chydoridae) and designation of a neotype from Sjaelsø, Denmark. Hydrobiologia 69:83-123.

Frey DG, 1982. Relocation of Chydorus barroisi and related species (Cladocera, Chydoridae) to a new genus and description of two new species. Hydrobiologia 86:231-269.

Frey DG, 1985. A new species of the Chydorus sphaericus group
(Cladocera, Chydoridae) from Western Montana. Int. Rev. Hydrobiol. 70:3-20.

Frey DG, 1987. The taxonomy and biogeography of the Cladocera. Hydrobiologia 145:5-17.

Frey DG, 1993. Species of Pleuroxus (Anomopoda, Chydoridae) from the subantarctic islands and southernmost South America: a partial unravelling of the Pleuroxus aduncus problem. Hydrobiologia 262:145-188.

Gorokhova E, Aladin N, Dumont HJ, 2000. Further expansion of the genus Cercopagis (Crustacea, Branchiopoda, Onychopoda) in the Baltic Sea, with notes on the taxa present and their ecology. Hydrobiologia 429:207-218.

Guindon S, Gascuel O, 2003. A simple, fast, and accurate algorithm to estimate large phylogenies by maximum likelihood. Syst. Biol. 52:696-704.

Gutierrez-Aguirre M, Suárez-Morales E, 2000. The Eurasian Thermocyclops crassus (Fischer, 1853) (Copepoda, Cyclopoida) found in southeastern Mexico. Crustaceana 73:705-714.

Hall TA, 1999. BioEdit: a user-friendly biological sequence alignment editor and analysis program for Windows 95/98/NT. Nucl. Acid. S. 41:95-98.

Haney RA, Taylor DJ, 2003. Testing paleolimnological predictions with molecular data: the origins of Holarctic Eubosmina. J. Evol. Biol. 16:871-882.

Huelsenbeck JP, Ronquist FR, Nielsen R, Bollback PJ, 2001. Bayesian inference of phylogeny and its impact on evolutionary biology. Science 294:2310-2314.

Jeffery NW, Elías-Gutiérrez M, Adamowicz SJ, 2011. Species Diversity and Phylogeographical Affinities of the Branchiopoda (Crustacea) of Churchill, Manitoba, Canada. PLoS ONE 6:e18364.

Keane TM, Creevey CJ, Pentony MM, Naughton TJ, Mcinerney JO, 2006. Assessment of methods for amino acid matrix selection and their use on empirical data shows that ad hoc assumptions for choice of matrix are not justified. BMC Evol. Biol. 6:29.

Kimura M, 1980. A simple method for estimating evolutionary rate of base substitution through comparative studies of nucleotide sequences. J. Mol. Evol. 16:111-120.

Koehn JD, Brumley AR, Gehrke PC, 2000. Managing the impacts of carp. Bureau of Rural Sciences of Canberra: 249 pp.

Korovchinsky NM, 2004. [Cladocerans of the order Ctenopoda of the world fauna (morphology, systematics, ecology, biogeography)].[Book in Russian]. KMK Press: 410 pp.

Kotov AA, 2009. A revision of Leydigia Kurz, 1875 (Anomopoda, Cladocera, Branchiopoda), and subgeneric differentiation within the genus. Zootaxa 2082:1-68.

Kotov AA, Taylor DJ, 2010. A new African lineage of the Daphnia obtusa group (Cladocera: Daphniidae) disrupts continental vicariance patterns. J. Plankton Res. 32:937-949.

Kotov AA, Taylor DJ, 2014. Daphnia lumholtzi Sars, 1885 (Cladocera: Daphniidae) invades Argentina. J. Limnol. 73:167-172.

Mergeay J, Verschuren D, Meester L, 2005. Cryptic invasion and dispersal of an American Daphnia in East Africa. Limnol. Oceanogr. 50:1278-1283.

Millette KL, Xu S, Witt JDS, Cristescu ME, 2011. Pleistocenedriven diversification in freshwater zooplankton: Genetic patterns of refugial isolation and postglacial recolonization in Leptodora kindtii (Crustacea, Cladocera). Limnol. Oceanogr. 56:1725-1736. 
Morgan DL, Gill HS, Maddern MG, Beatty SJ, 2004. Distribution and impacts of introduced freshwater fishes in Western Australia. New Zeal. J. Mar. Fresh. 38:511-523.

Müller OF, 1776. [Zoologiae Danicae Prodromus, seu Animalium Daniae et Norvegiae Indigenarum characteres, nomina et synonyma imprimis popularium].[Book in Latin]. Havniae, typis Hallageriis: 274 pp.

Müller OF, 1785. [Entomostraca seu Insecta Testacea, quae in aquis Daniae et Norvegiae reperit, descripsit et iconibus illustravit].[Book in Latin]. Lipsiae et Havniae: 135 pp.

Panov VE, Rodionova NV, Bolshagin PV, Bychek EA, 2007. Invasion biology of ponto-caspian onychopod cladocerans (Crustacea: Cladocera: Onychopoda). Hydrobiologia 590:3-14.

Posada D, Buckley TR, 2004. Model selection and model averaging in phylogenetics: advantages of akaike information criterion and Bayesian approaches over likelihood ratio tests. Syst. Biol. 53:793-808.

Richard J, 1894. [Cladoceres recueillis par le Dr. Theod. Barrois en Pelestine, en Syrie et en Égypte].[Article in French]. Rev. Biol. Nord Francee 6:360-378.

Sacherová V, Hebert PDN, 2003. The evolutionary history of the Chydoridae (Crustacea: Cladocera). Biol. J. Linn. Soc. 79:629-643.

Shiel RJ, Dickson JA, 1995. Cladocera recorded from Australia. T. Roy Soc. South Aust. 119:29-40.

Sinev AY, Kotov AA, 2012. New and rare Aloninae (Cladocera: Anomopoda: Chydoridae) from Indochina. Zootaxa 3334:1-28

Sites JWJ, Marshall JC, 2004. Operational criteria for delimiting species. Annu. Rev. Ecol. Evol. S. 35:199-227.

Smirnov NN, 1971. [Chydoridae of the world fauna. Fauna SSSR].[Book in Russian]. Nauka: 531 pp.

Smirnov NN, 1976. [Macrothricidae and Moinidae of the world fauna. Fauna SSSR, novaya seriya].[Book in Russian]. Nauka: 237 pp.

Smirnov NN, 1995. Check-list of the Australian Cladocera (Crustacea). Arthropoda Selecta 4:3-6.

Smirnov NN, 1996. Cladocera: the Chydorinae and Sayciinae (Chydoridae) of the world. Guides to the identification of the microivertebrates of the continental waters of the world. SPB Academic: $197 \mathrm{pp}$.

Smirnov NN, Sheveleva NG, 2010. [Chydorus irinae sp. n. (Anomopoda, Chydoridae, Chydorinae) from the Tom'
River (the Amur basin, Russia)].[Article in Russian]. Zoologichesky Zhurnal 89:635-638.

Smirnov NN, Timms BV, 1983. A revision of the Australian Cladocera (Crustacea). Australian Museum: $132 \mathrm{pp}$.

Sorensen KH, Sterner RW, 1992. Extreme cyclomorphosis in Daphnia lumholtzi. Freshwater Biol. 28:257-262.

Suárez-Morales E, Gutiérrez-Aguirre MA, Torres JL, Hernández F, 2005. The Asian Mesocyclops pehpeiensis Hu, 1943 (Crustacea, Copepoda, Cyclopidae) in Southeast Mexico with comments on the distribution of the species. Zoosystema 27:245-256.

Sukhikh NM, Souissi A, Souissi S, Alekseev VR, 2013. Invasion of Eurytemora affinis sibling species (Copepoda: Calaniformes) from North America into the Baltic Sea and European Atlantic coast estuaries. J. Nat. Hist. 47:753-767.

Suthers MI, Rissik D, 2009. Plankton: a guide to their ecology and monitoring for water quality. CSIRO Publishing: $272 \mathrm{pp}$.

Tamura K, Peterson D, Peterson N, Stecher G, Nei M, Kumar S, 2011. MEGA5: molecular evolutionary genetics analysis using maximum likelihood, evolutionary distance, and maximum parsimony methods. Mol. Biol. Evol. 28:2731-2739.

Thompson JD, Higgins DG, Gibson TJ, 1994. CLUSTAL W: improving the sensitivity of progressive multiple sequence alignment through sequence weighting, position specific gap penalties and weight matrix choice. Nucleic Acids Res. 22:4673-4680.

Van Damme K, Sinev AY, Dumont HJ, 2011. Separation of Anthalona gen.n. from Alona Baird, 1843 (Branchiopoda: Cladocera: Anomopoda): morphology and evolution of scraping stenothermic alonines. Zootaxa 2875:1-64.

Van Damme K, Sinev AY, 2013. Tropical Amphi-Pacific disjunctions in the Cladocera (Crustacea: Branchiopoda). J. Limnol. 72(Suppl.2):209-244.

Xu S, Hebert PDN, Kotov AA, Cristescu MEA, 2009. The noncosmopolitanism paradigm of freshwater zooplankton: insights from the global phylogeography of the predatory cladoceran Polyphemus pediculus (Crustacea, Onychopoda). Mol. Ecol. 18:5161-5179.

Yan ND, Girard R, Boudreau S, 2002. An introduced invertebrate predator (Bythotrephes) reduces zooplankton species richness. Ecol. Lett. 5:481-485.

Zanata LH, Espíndola ELG, Rocha O, Pereira RHG, 2003. First record of Daphnia lumholtzi (Sars, 1885), exotic cladoceran, in São Paulo state (Brazil). Braz. J. Biol. 63:717-720. 